Vol. 22, $n^{\circ} 1 \mid 2018$

Varia

\title{
Punishment and Labour Relations. Cuba between Abolition and Empire (1835-1886)
}

Christian G. De Vito

\section{(2) OpenEdition}

Electronic version

URL: http://journals.openedition.org/chs/2128

DOI: $10.4000 /$ chs. 2128

ISSN: 1663-4837

Publisher

Librairie Droz

Printed version

Date of publication: 31 October 2018

Number of pages: 53-79

ISSN: 1422-0857

\section{Electronic reference}

Christian G. De Vito, "Punishment and Labour Relations. Cuba between Abolition and Empire

(1835-1886)", Crime, Histoire \& Sociétés / Crime, History \& Societies [Online], Vol. 22, n¹ | 2018, Online since 31 December 2020, connection on 12 January 2021. URL: http://journals.openedition.org/chs/ 2128 ; DOI: https://doi.org/10.4000/chs. 2128 


\title{
Punishment and Labour Relations
}

\author{
Cuba between Abolition and Empire (1835-1886)
}

\author{
Christian G. De Vito²
}

\begin{abstract}
This article argues for a greater focus on the plural functions that forms of punishment have played in connection with labour relations within given historical contexts. To this end, it introduces the concept of "punitive pluralism", expands the notion of labour to include all forms of labour relations ("free" and "unfree"), and discusses the impact of the simultaneous pluralization of punishment and labour on the analysis of their interconnections. The entanglements between punishment and labour relations are addressed here via a case study of Cuba in the decades between the second Anglo-Spanish treaty for the abolition of the slave trade (1835) and the end of the apprenticeship system, or patronato (1886), that followed the abolition of slavery on the island (1880).
\end{abstract}

Cet article plaide pour une plus grande focalisation sur les fonctions plurielles que les formes de punition ont joué en connexion avec les relations de travail dans des contextes historiques spécifiques. En conséquence, il introduit le concept de "pluralisme punitif», élargit la notion de travail à toutes les formes de relations de travail ( libre » et «non libre») et traite de l'impact de la pluralisation de la peine et du travail sur l'analyse de leurs interconnexions. Les enchevêtrements entre la punition et les relations de travail sont abordés ici via une étude de cas de Cuba dans les décennies entre le deuxième traité Anglo-Espagnol pour l'abolition de la traite des esclaves (1835) et la fin du système d'apprentissage, ou patronato (1886), cela a suivi l'abolition de l'esclavage sur l'île (1880).

\section{PUNISHMENT AND LABOUR RELATIONS: CHANGING THE FRAME}

When scholars have sought to conceptualize the connection between punishment and labour relations, they have hitherto taken a markedly Eurocentric perspective, embraced a linear vision of the evolution of labour and

1 The research underpinning this article received funding under the European Union's Seventh Framework Programme (ERC Grant Agreement 312542). The project "The Carceral Archipelago: Transnational circulations in global perspectives, 1415-1960" was based in the School of History, Politics and International Relations, University of Leicester. The author wishes to thank the three anonymous peer reviewers and Iacy Maia Mata, Viola Müller, Maria Luisa Pesante, Michele Reid-Vazquez, Maeve Ryan, Juliane Schiel and Paulo Terra for their insightful comments on earlier versions of the article.

2 Christian De Vito is Researcher in History and coordinator of the Junior Research Group "Punishment, Labour, Dependency" at the University of Bonn (within the Centre for Dependency and Slavery Studies). His current research focusses on transportation and convict labour in the Spanish Empire during the eighteenth and nineteenth centuries, and he has published on the history of punishment, labour history and global history (De Vito \& Lichtenstein, 2015; De Vito, Futselaar \& Gevers, 2016; De Vito \& Gerritsen, 2018). 
punishment, and offered binary interpretations that connect one type of punishment with one type of labour relations. ${ }^{3}$ These three features are especially visible in studies of imprisonment and wage labour, where two teleological assumptions collide: the conflation of the (Western) penitentiary with modernity and the tendency to see the shift towards wage labour as a universal corollary of modernity. Accordingly, major criminological theories (such as those of Foucault, and Melossi and Pavarini) have systematically marginalized, or ignored altogether, the majority of the punishments and labour relations that have emerged in human history, even in the periods analysed by such authors.

Such views of a rather mechanistic relationship between punishment and labour were primarily produced by social scientists during the 1970 s and early 1980 s. Since then, new historiographies of both labour and punishment have emerged that provide the empirical basis for a thorough reconceptualization of the issue. In particular, scholars in the area of global labour history highlighted the need to address the multiplicity of labour relations that have been implicated in the process of labour commodification. ${ }^{4}$ Moving beyond the standard conflation of labour history with the history of wage labour, as well as overcoming the tendency to study slavery in isolation, this perspective invites the simultaneous study of all labour relations and foregrounds their entanglements, moving beyond the traditional distinction between "free" and "unfree" labour relations.

At the same time, in the field of the history of punishment many empirical studies have moved away from narratives of a linear transition from corporal punishment to the penitentiary, and towards more articulated histories of the co-existence and connectedness of multiple forms of punishment (not only in so-called "pre-modern" societies, but also in contemporary polities). ${ }^{5}$ Recent contributions to a nonteleological reconceptualization of the history of punishment have demonstrated that during the period from the nineteenth to the twenty-first centuries, long depicted as "the age of the triumphant prison", the impact of the penitentiary was limited in many (primarily colonial) contexts. Multiple studies have proved its persistent co-existence with forced labour, corporal punishment and other punitive regimes, including penal colonies, labour and concentration camps and detention centres for undocumented migrants and asylum seekers. ${ }^{6}$ At the same time, especially within the connected fields of Atlantic slavery and colonial and imperial histories, efforts have been made to propose broader and more dynamic conceptualizations of punitive regimes. In particular, Benton and Ross, and Duve, have argued for the potential of the concept of "legal pluralism" for historical analysis. ${ }^{7}$ Sherman has proposed the concept of "coercive networks" as a tool to examine "the various colonial institutions and practices [of punishment] in a single frame, and as a function of larger political, administrative, economic, social and cultural processes". 8

Melossi \& Pavarini (1981); Foucault (1975); Sellin (1976, p. xviii).

$4 \quad$ Brass and van der Linden (1997); Lucassen (2006); van der Linden (2008).

5 See, for examples focussed on a range of periods, Lo Basso (2004); Barrio Gonzalo (2006); Claustre (2007); Geltner (2008); Martínez Martínez (2011); Sánchez-Arcilla Bernal (2012); Washburn (2013); Groen-Vallinga, Tacoma (2015); Rio (2015).

6 See, among many others: Gibson (2011); Moran, Gill, Conlon (2013); Wachsmann (2015); De Vito, Futselaar, Grevers (2017); Anderson (2018); De Vito, Anderson, Bosma (2018).

7 Benton and Ross (2013). Duve $(2014,2016)$.

8 Sherman (1999, p. 674). 
At the crossroad of these developments in the history of labour and punishment, a new field of research can be imagined that addresses systematically the plural functions that various types of punishment have simultaneously played in connection with multiple labour relations within given contexts throughout human history. This article is a contribution to this endeavour. To this end, it takes a double move, aimed to pluralise both labour and punishment. On the one hand, the essay embraces the approach suggested by global labour historians, and view the co-existence and entanglement among all forms of ("free" and "unfree") labour relations as the standard in human history. ${ }^{10} \mathrm{On}$ the other hand, from the perspective of the study of punishment, the concept of "punitive pluralism" is introduced to address the various types of punishment that have been imbricated in the shifts in labour relations. This concept builds on the scholarly discussion on "legal pluralism" and retains three of its key features, namely: viewing the simultaneity of multiple legal systems within the same society as the standard in history; foregrounding the fact that state law itself is plural; and highlighting the plural character of imperial legal orders. In turn, this essay contends that the concept of "punitive pluralism" can add three extra dimensions to the analysis, as it: expands the focus beyond the legal system, to include administrative enforcement and military justice; foregrounds "punishment", whereas the literature on legal pluralism is mainly concerned with sentencing; and highlights the tensions produced by those forms of punishment that implied relocation across imperial spaces. All in all, "punitive pluralism" allows addressing at once all practices of punishment within a given historical context, including private- and state-administered punishments, incarceration and penal transportation, banishment and all types of administrative measures. As such, it provides a tool to study the logic of the entanglements, co-existence and shifts in punitive practices.

The simultaneous pluralization of labour and punishment is the necessary basis for a fully historical understanding of their entanglements. In the conclusion of this article it will be discussed how this perspective reshapes the view of the connections between punishment and labour relations. To that end, the analytical frame proposed in this section will be brought together with the empirical evidences presented in the pages that follow.

\section{CUBA BETWEEN ABOLITION AND EMPIRE}

This article investigates the connections between punishment and labour relations via a case study of Cuba in the decades between the second Anglo-Spanish treaty for the abolition of the slave trade (1835) and the end of the apprenticeship system, or patronato (1886), that followed the abolition of slavery on the island (1880). Cuba in that period represents a useful vantage point for the study of this issue, due to the richness and complexity of both the forms of punishment and labour relations. Between the late eighteenth and the early nineteenth centuries, the Caribbean island underwent a combined transformation into a plantation and

9 This assumption underpins the research program of the Junior Research Group "Punishment, Labour, Dependency" (co-ordinated by the author) at the University of Bonn's Centre for Dependency and Slavery Studies.

10 De Vito, Schiel \& van Rossum (forthcoming). 
slave society, and eventually became the world's largest producer of sugar. ${ }^{11}$ In the process, the quantitative and ethnic profile of the population changed dramatically. Of the 171,500 inhabitants in $1775,96,400$ were white $(56 \%), 36,300(21 \%)$ were free persons of colour and 38,900 (23\%) were enslaved Africans. Conversely, the 1841 census counted slightly over one million inhabitants, of whom 418,291 (around 41\%) were whites, 152,838 free coloured (c.15\%) and 436,495 (c.43\%) enslaved workers. The economic and political profits brought by that rapid change played a key role in maintaining Cuba within the orbit of the Spanish monarchy in the turmoil triggered by the independence of Latin America (1810s-1830s). At the same time, imperial and local elites perceived such economic growth based on slavery as a risky endeavour and especially feared a slave rebellion modelled on the Haitian revolution. ${ }^{12}$ The latter never fully materialised in Cuba but planters, politicians, intellectuals and magistrates - elite groups that often overlapped frequently invoked it in order to legitimise multifaceted repressive measures against the black population. Simultaneously, many among the free blacks and the enslaved people did engage in ethnically and socially-mixed anti-colonial revolts and wars throughout the nineteenth century.

Parallel to those developments, in the decades addressed by this article, a broad debate took place about the "labour question", that is, on the type of workforce that would have ultimate superseded slavery, and on the appropriate ethnic balance on the island more generally. ${ }^{13}$ Not only was slavery gradually to be phased out - some argued - but a broader process of "whitening" (blanqueamiento) of the workforce also had to take place. Demographic transformations in the central decades of the nineteenth century reflected the outcomes of such debate and the contradictory interests behind it: whereas 246,798 enslaved Africans were still imported into Cuba between 1840 and 1867 , by 1862 the white population once again formed the majority $(53.7 \%)$ of the $1,359,238$ inhabitants of the island.

From the late eighteenth century to the 1880 s, labour relations shifted according to those broader changes. First, slavery became the leading labour relation on the island as a result of the transition from the focus on the defence system to the centrality of the plantation economy. Then, especially from the 1840 s, a process of differentiation of labour relations took place, with variable combinations of statesponsored migrants from Spain and the Canary Islands, convict labour and Chinese and Yucatecan indenture complementing the enslaved workforce. Finally, after the end of the patronato, the labour market was unified under a regime of wage labour internally characterized by distinct types of contracts and various degrees of coercion. During the whole period, moreover, significant differences in the composition of the workforce existed on the island, especially between the western plantations, the eastern rural areas and the urban centres. This resulted in distinct patterns in the shifts of labour relations.

These intertwined historical processes are well-known, but what role did punishment play in enhancing such transformations? Each of the sections that follow investigates one area where punishment and labour relations interacted. They do not address all possible aspects of these interactions - most notably, the focus here is

\footnotetext{
11 Knight (1970); Ferrer (1999); Scott (2000).

12 González-Ripoll et al. (2004); Ferrer (2014).

13 Naranjo Orovio and García González (1996); Ghobrial (2009).
} 
primarily on punitive and labour regimes related to men. However, they are designed to highlight the wide reach of punitive practices vis-à-vis different groups of the population and various regions of the island. The first section below highlights how policies of social control, backed by specific repressive and preventive practices of expulsion, were directly aimed to first preserve slavery and then favour a regulated and gradual transition beyond it. The second section discusses the role of both domestic and state-enforced punishment in governing the mixed workforce of the plantations of Western Cuba, while simultaneously pointing to punishment as an area of workers' individual and collective agency. The focus then shifts to the making of convict labour and its role among other types of labour relations, both in Cuba and across other sites of the Spanish empire. In the fourth section, anti-vagrancy policies take centre-stage as a highly dynamic punitive tool to control the urban and rural populations, and as a way to both expel and immobilize distinct social groups. In the concluding remarks the overall significance of the simultaneous analysis of punitive pluralism and multiple labour relations is discussed.

\section{PATROLLING THE CORDON SANITAIRE, EXPELLING THE "INTERNAL ENEMIES"}

Following the Seven Years War (1754-1763) and up to the early nineteenth century, Cuba was a key destination for imperial penal transportation. ${ }^{14}$ In those decades, thousands of convicts were sent to the island from Spain, the Viceroyalty of New Spain and the other Spanish dominions in the Caribbean. Their labour, together with that of the king's slaves, was central in the construction and maintenance of the military infrastructure on the island. Moreover, convicts were impressed in the garrisons of the island and, particularly from the 1790s onwards, were involved in public works. The independence of Latin America altered this picture by limiting Cuba's penal connections to Spain, the Philippines, the North African military settlements (presidios) and Puerto Rico (the latter being the only other remaining possession in the Americas). Then, on 26 December 1836, a royal order established the "suspension of the confinement of individuals of all classes in the overseas Provinces" as a consequence of the "critical circumstances" experienced in those dominions. ${ }^{15}$

The decision to reverse the decades-long policy on convict transportation is telling of the fragile political balance of the island across the nineteenth century, torn between the endogenous instability of empire, Cuba's peculiar contradictions as a slave society in constant fear of a slave revolution, and consistent and multifaceted external political and economic pressures. The same concerns guided the local authorities in their surveillance of any Spanish or foreign individual entering Cuba. All pointed to the need to build a cordon sanitaire around the island's expanding yet threatened richness, which in those early decades of the nineteenth century amounted to preserving the institution of slavery and the planters' full control of the largely enslaved workforce more generally.

14 See Jennings (2016), De Vito (2018a; 2018b).

15 Archivo General Militar - Madrid (AGMM), 5774.10. For an overview and discussion of punishment in the Spanish empire during the nineteenth century see De Vito (2018c). 
In 1835 Spain signed a second treaty with Britain for the abolition of the slave trade. This did not prevent thousands more enslaved Africans being brought illegally to the island in the subsequent three decades, but it made clear that the days of slavery were numbered - a message that had not been as strong when the first Anglo-Spanish treaty had been signed in 1817. Two years earlier, in 1833, the British Parliament had abolished slavery throughout its empire. In the pamphlet that celebrated that event, the British abolitionist society explicitly stated that it would now extend its action "to the countries where there are slaves" by sending its emissaries. ${ }^{16}$ The search and expulsion of such "negrophile fanatics" (fanáticos negrófilos) became a priority for the Cuban authorities, with the explicit goal of securing the plantation economy and the racial hierarchy at large. Preventive measures included forbidding access to any person deemed subversive and limiting the mobility of those authorised to enter the island for work-related reasons, with special care taken to prohibit their access to rural areas. Repressive measures featured expulsions based on the exceptional powers conceded to the Captains general and sentences pronounced by the Military Commission established in Cuba in March 1824. Between 17 July 1835 and 17 October 1842 alone, the latter sentenced 831 individuals, of whom 153 for "rebellion against the established order", 95 for "subversive words" and 583 for "conspiracies of slaves and emancipated". ${ }^{17}$

In the everyday practice of administrative and judicial institutions, the expulsion of those coming from abroad to seek the abolition of slavery overlapped with the repression of residents in Cuba who were suspected of activities in favour of the independence of the island or its annexation to the USA. In both cases, the goal was the expulsion of undesirables who allegedly endangered the political, social and racial stability of the colony. Deportations of this kind punctuated the 1850 s and the 1860s; then, during the Ten Year War (1868-1878) and the Little War (1879$1880)$, this punitive practice took on a mass and permanent character. ${ }^{18}$ Besides the hundreds of armed insurgents (including enslaved workers, free people of colour and Chinese contract workers) who were executed and court marshalled to the North African presidios of Ceuta, Melilla and Chafarinas, many more faced administrative deportation to Spain, the Baleares and Canary Islands and the island of Fernando Poo in the Gulf of Guinea. Doctors, planters, lawyers and intellectuals for the vast majority, the latter were deemed laborantes, or suspects of supporting the insurrection from their privileged positions in Havana. In some cases they were accused of arming groups of slaves against the Spaniards.

Long before the question of abolition effectively converged with proindependence insurgency, the Cuban elite had conceptualised enslaved Africans, and the "race of colour" (raza de color) more broadly, as an internal enemy. In pursuit of a "safer" ethnic balance, or (as they put it) the "whitening" (blanqueamiento) of the population, two methods were adopted. On the one hand, "white" migration was favoured and, to that end, schemes were designed to bring in European workers, then Maya indentures from Yucatan and finally, in 1848 and between 1853 and 1873, over

16 Archivo Histórico Nacional (AHN), Ultramar, 3547, exp. 7, Havana, 3.10.1835.

17 Llaverías (1929, p. 72-107, quote at p. 109). For another case: AHN, Ultramar, 5063, exp. 35, Puerto Rico, 11.3.1841, n. 58. Exceptional powers were given to the Captains General by the Royal Orders of 28.3.1825, 21.3.1834 and 26.5.1834.

18 See for example AHN, Ultramar: 4645, exp. 4 and exp. 9; 4646, exp. 73. On the deportation of laborantes see esp. AHN, Ultramar, 4777. 
120,000 Chinese "coolies" - the latter two groups being conceptualized as "whites" too. ${ }^{19}$ Reducing the number of black people was the flipside of the blanqueamiento policy and free people of colour (libres de color) became its main target. Indeed, the authorities made little effort to hide their view that the very presence of free blacks in a slave society was contradictory and could undermine the institution of slavery and the political order. As early as 1832, the Captain general Francisco Dionisio Vives viewed the expulsion of all free blacks as an ideal option, albeit one too difficult to implement.$^{20}$ Especially for groups with a particularly weak status, such as the emancipados (those individuals liberated during operations against the illegal slave trade), there was hardly the need of legal or administrative justifications for their expulsions from the island. Following a Royal Order of 5 April 1861, for example, two hundred emancipados were relocated to the public works on Fernando Poo on the blunt premise that by remaining in Cuba they would contribute to "enhance the evil of which free blacks are always a cause". ${ }^{21}$

The libres de color as a whole were constantly feared for their potential alliance with the enslaved people. Moreover, expelling them also had a more direct impact on the labour market, for it meant destabilizing their traditional occupation in the militia of colour and disarticulating their presence, and at times virtual monopoly, in significant sectors of the urban labour market (from day labourers to carpenters, masons and midwives). ${ }^{22}$ Although their individual economic contribution was sometimes praised by local authorities, the latter increasingly shared the opinion of influential reformers who insisted that the competition of libres de color prevented the white population from entering those occupations and therefore condemned it to vagrancy and destitution. From this perspective, the banishment of the free blacks was instrumental to their substitution by "white" workers in those sectors.

The most successful attempt of the Cuban elite to reduce and de-structure the free black community on the island came with the draconian repression that followed the slave insurrections of 1843, usually referred to as La Escalera conspiracy. ${ }^{23}$ The extensive scholarship on the issue has centred on whether such a combined conspiracy actually existed or whether it was fabricated by the authorities to legitimize largescale repression. However, Reid-Vazquez has convincingly shifted the focus to "the indisputably real repression and its impact on the free population of African descent and colonial Cuban race relations". ${ }^{24}$ She has calcualated that the libres de color did not just represent $67 \%$ of the total 1,836 individuals sentenced by the Military Commission, but also a staggering $99,5 \%$ of the 435 who were banished. Moreover, the free blacks made up $70 \%$ of the over 1,800 individuals sentenced by ordinary courts to overseas imprisonment, mainly in Ceuta. Finally, by a Royal Decree of

19 Yun (2008, p. 19); Helly (1979); Hu-DeHart (1994). On yucatecos transported to Cuba: Álvarez Cuartero (2007).

20 Reid-Vazquez (2011, p. 27).

21 Published in Salmorál (2005, p. 333-334). For a detailed analysis of the fate of the Cuban emancipados: Roldán de Montaud (1982). For a comparative analysis: Sofela (2011).

22 Reid-Vazquez (2011, esp. chapter 1).

23 Paquette (1988); Reid-Vazquez (2011); Finch (2015).

24 Reid-Vazquez (2011, p. 8 and p. 58-60). The libres de color made up $48.7 \%$ of the 78 executed, $52.9 \%$ of the 1,165 imprisoned and $58 \%$ of the 31 sentenced to workhouses and lighter punishment: (footnote 5, p. 181-182). 
the captain general dated 31 May 1844, all foreign-born free people of colour were expelled.

The repression carried out during the "year of the lash" of 1844 had lasting consequences for the Cuban free black community and it was only by the late 1850s that the libres de color were able to regroup again in the island. However, the insurrection that started in Eastern Cuba in 1868 and continued through the end of the Little War in 1880 created new opportunities for scapegoating the free black population. Indeed, framing the multi-ethnic insurrection as a "race war" waged by the raza de color against the whole white community proved a major feature in colonial propaganda. Unsurprisingly, the local authorities took advantage of the circumstances to target sections of the free black population for expulsion within broader streams of deportation, as in the case of the forced relocation of 265 libres de color from Eastern Cuba to Fernando Poo, directed by the Military commander and Governor of Santiago de Cuba, Camilo Polavieja, in December 1880. ${ }^{25}$

Repression against free blacks was neither limited to the "year of the lash" nor uniquely connected with their participation in the struggle for Cuban independence. It rather punctuated the aftermath of many real or alleged slave conspiracies on the island. Moreover, it featured a long-term continuity vis-à-vis specific groups within the "raza de color". The persecution of the members of the Abakuá mutual aid society, or ñañigos, is an especially clear case, starting in the 1830s and continuing even beyond the abolition of slavery and the independence of the island from Spain. ${ }^{26}$ The Abakuá society in Cuba was modelled after the Ékpè leopard societies of the Cross River basin, in the West African Old Calabar, the place of origin of some of the enslaved workers transported to the Caribbean island. Starting in 1836 with the creation of the first lodge (juego) outside the city-walls of Havana, the Society expanded rapidly and by the mid-1840s forty lodges existed in the Cuban capital. In Havana as well as in other cities, the Abakuá became closely associated to port areas, exercised a full control on the recruitment of workers in the docks and controlled the guild of the tobacco workers. ${ }^{27}$ For that reason, they additionally attracted white creoles, Chinese "coolies" and some American Indians, whose initiations, after 1857 , were explicitly aimed at the double goal of "liberty for slaves and liberty for Cuba". ${ }^{28}$

The strong presence of the Abakuás among the urban workers and their growingly inter-ethnic background made them a primary target of the repression. Starting in 1839 , waves of arrests were unleashed with regularity against the ñañigos, who were constructed as the ultimate example of African "barbarism" and criminality. ${ }^{29}$ Every occasion was taken to search, imprison and deport the members of the Society, and especially those among them who belonged to the "raza de color": included in the deportations following the Escalera and during the Ten Year War, and relocated as vagrants in 1866 and under the anti-banditry law in 1877, the Abakuás were transported as far as Spain, the Canary Islands, Ceuta, Chafarinas and Fernando Poo. The second half of the 1870 s and the early 1880 s, coinciding with the final years of

Ferrer (1999, p. 8); Maia Mata (2016).

26 See especially: Miller (2009). See also: Helg (1995, p. 83 and p. 107-116).

27 de Aranzadi (2012, esp. p. 39).

28 Miller (2009, p. 107).

29 See esp. Trujillo y Monagas (1882); Roche y Monteagudo (1908); Ortiz (1950). 
slavery, was a period of particularly harsh repression. After a police raid took place in Havana on 13 March 1876 and resulted in the deportation to the Isle of Pines of over 140 ñañigos, in August the same year a ban on all Abakuá meetings was introduced, followed by the 1880 ban on wearing related masks in the streets and a broader ban on all processions of the cabildos on the Day of the Three Kings (Dia de los reyes), first implemented on 6 January $1884 .{ }^{30}$ New deportations followed, including those of nearly six hundred ñañigos sent in 1895-96 to Fernando Poo, Ceuta and the prisons of Figueras and Santoña in Spain. Excluded from the general amnesties of 17 May 1897 and 15 October 1897 as "individuals of perverted behaviour and accustomed to crime", they were only allowed to return to Cuba in early 1899, after the sovereignty of the island had passed to the US military administration. ${ }^{31}$

\section{PLANTATION WORKERS AND THE LAW}

The enslaved workforce was the backbone of the Cuban elites' power and a continual concern. Even before the slaves' active participation in the insurrection, continuous episodes of everyday resistance, sabotage, escapes and revolts marked the Cuban plantations. ${ }^{32}$ Contrary to foreign abolitionists, insurgents, laborantes and libres de color, however, the enslaved workers were not an "internal enemy" one could expel en masse, for that would have undermined the very basis of Cuba's economic development. Accordingly, their punishment had to be calibrated through a more subtle dialectics of immobilisation and expulsion. Indeed, even in the midst of the brutal repression of the "year of the lash", while the free blacks were systematically sentenced to deportation and exile, the Military Commission primarily sentenced slaves to exemplary capital punishment, on the one hand, and, on the other, to the work brigade attached to the Havana prison, to "imprisonment in the ranches of their masters" and to a fixed amount of lashes to be administered in the plantations..$^{33}$

A similar mechanism emerged in relation to cases of murder collectively performed by enslaved Africans against their masters or against the overseers, slave drivers and fellow workers. The slave owners usually attempted to punish in their plantation all or the majority of the implicated slaves. In the latter case, they handed out a few alleged ring-leaders to the public prosecutors, who would usually sentence them to ten years of penal transportation and two extra years of "retention" (retención), depending on their conduct. The slave owners were entitled to monetary compensation for the "loss" of the slaves punished by the public authorities. Moreover, at the end of the period of punishment, the enslaved workers were given back to their masters, resold into captivity or, if this proved impossible, became part of the crown's slaves. Their punishment might also be accompanied by the administering of fifty to two hundred lashes on the plantation or in public, and by

\footnotetext{
30 AHN, Ultramar, 4740, exp. 62, Havana, 13.3.1876.

31 For detailed data: AHN, Ultramar, 5007, exp. 25.

32 See esp. Barcia (2008).

33 Llaverías (1929, from p. 151). See also the sentences in the Escoto collection, Harvard University: https://iiif.lib.harvard.edu/manifests/view/drs:45013179\$1i (5 Dec. 2017). On punishment of slaves sentenced for murders in the plantations: Ortiz-Minaya (2014).
} 
rituals of public shaming. In other cases, corporal and shaming punishment in the plantation were simply followed by reselling of the captives to new masters.

The balance between immobilisation and expulsion therefore related to the dialectic between punishments administered by the slave owners and state-enforced punishments. This stemmed from a complex interplay of power. Both the slave owners and the State needed to enhance their authority by reaffirming their right to punish the enslaved workers. At the same time, the State had to balance its authority with the property rights of the slave owners. And the latter had to weigh their right to punish against their economic interests, on the one hand, and, on the other, with the need to prevent larger disruptions of their autoridad dominica (master's authority) that could derive from an untimely and openly-abusive repression. Most decisions were taken "on the spot", depending on the specific circumstances of the crime, the slaves and the owners involved, and the broader situation in the plantation and in the Cuban society as a whole. To make things more complex, this dynamic took place in a social environment where the slave owners and the policy-makers at least partially overlapped. Thus, the "private" and "public" functions of punitive institutions were no less ambiguous. Slave owners could temporarily "deposit" their enslaved workers in the public jails or ask for public whipping as externalized domestic punishments for minor crimes; and runaway slaves were held in the public depositos de cimarrones awaiting for their owners to collect them (and pay related expenses), or otherwise be sold to new owners or become property of the State.

Table 1 (below) summarises the main features of the relationship between stateadministered and domestic punishments of the plantation slaves in relation to the four largest groups of crimes:

Table 1. State-administered and domestic punishments regarding selected crimes.

\begin{tabular}{|c|c|}
\hline Crime & $\begin{array}{l}\text { Dialectics between state-administered and domestic } \\
\text { punishments }\end{array}$ \\
\hline Theft and "indiscipline" & $\begin{array}{l}\text { - Primarily, on-plantation punishments: whipping, dungeons, } \\
\text { stocks, chains, etc. } \\
\text { - Temporary use of public institutions by the slave owners } \\
\text { (jails, public whipping). } \\
\text { - State-administered punishment and private interest to } \\
\text { remove the "incorrigibles". }\end{array}$ \\
\hline $\begin{array}{l}\text { Murder of owner, } \\
\text { overseer and slave } \\
\text { drivers }\end{array}$ & $\begin{array}{l}\text { - Slave owners select a limited group of perpetrators for } \\
\text { state-administered punishments (capital punishment and/ } \\
\text { or transportation following commutation); the rest of the } \\
\text { perpetrators are punished in the plantation. } \\
\text { - Cases of slave owners' omission to report these crimes } \\
\text { altogether to the public authorities, in order to punish them } \\
\text { exclusively in the plantation. }\end{array}$ \\
\hline
\end{tabular}




\begin{tabular}{|l|l|}
\hline Marronage (desertion) & $\begin{array}{l}\text { Public and private intervention in the capture (and its } \\
\text { funding). }\end{array}$ \\
\hline $\begin{array}{l}\text { Insurrection and } \\
\text { Conspiracy }\end{array}$ & $\begin{array}{l}\text { The enslaved worker is temporary held in the depositos de } \\
\text { cimarrones, then returned to the slave owners or employed } \\
\text { in public works. }\end{array}$ \\
\hline $\begin{array}{l}\text { State-administered punishment of the (alleged) ring-leaders, } \\
\text { usually with the consensus of the slave owners. Monetary } \\
\text { compensation of the slave owners possible under certain } \\
\text { circumstances. } \\
\text { On-plantation punishment of the other (alleged) conspirators. }\end{array}$ \\
\hline
\end{tabular}

A striking characteristic of punishment related to the plantation workers in Cuba lies in the fact that the dialectic between domestic and state-administered punishments did not simply apply to the slaves, but also (at least) to Chinese contract workers. Escaped "coolies" were hunted down under the conditions established by the 1796 Reglamento de cimarrones. ${ }^{34}$ Just like the enslaved workers, once recaptured they were temporarily held in the depositos de cimarrones waiting for the landowner to collect them or employed in public works under State's jurisdiction. Punishment for murders committed by the indentured workers in the plantations also closely followed the pattern of punishment for analogous crimes by slaves ${ }^{35}$ Here, too, landowners tried to minimize their economic loss by enhancing on-plantation punishment and magistrates balanced public punishments with the restitution of guilty contract workers to the landowners. Chinese coolies and enslaved people of African descent were also sentenced together, and to the same punishments and destinations, when they committed crimes together.

Philip Foner has written that the Chinese workers were "bought, sold, and transferred like slaves, and treated as slaves". Indeed, they were also punished as slaves.$^{36}$ Moreover, they saw themselves treated as slaves and vehemently reacted against it. To that end, besides committing suicide and escaping from the plantations, they used legal instruments such as petitions and manipulated punishment, in particular by squeezing themselves into the dialectics between the landowners and the public magistrates. The Spanish authorities repeatedly noticed that Chinese workers felt legitimized to respond with violence to the abusive punishments received from the overseers and were likely to confess collectively those crimes that they perceived as a form of justice..$^{37}$ This was clearly not how magistrates framed it, but while some judges prejudicially sided with the landowners, others accepted the workers' accusations and besides mitigating their punishment, they exposed the "sordid interests of the masters [patronos]" and imposed fines on the land-owners. ${ }^{38}$ After receiving their sentences, Chinese contract workers massively petitioned from

$34 \quad$ La Rosa Corzo (2003); Yacou (2009).

35 Dorsey (2004). For some court cases: AHN, Ultramar, 2078, exp. 4, Sagua la Grande, 27.9.1858; AHN, Ultramar, 2080, exp. 23, Matanzas, 7.9.1872; AHN, Ultramar, 2081, exp. 4.

36 Foner (1962, p. 224).

37 AHN, Ultramar, exp. 4, Sagua la Grande, 27.9.1858.

38 AHN, Ultramar, 2078, exp. 3, Sagua la Grande, 13.6.1872. For other cases: AHN, Ultramar: 2080, exp. 14, Villa de Guanejay, 17.8.1861; 2078, exp. 3, Matanzas, 22.1.1863. 
the sites of deportation and prompted the Chinese government to send an imperial mission to Cuba. The indentured workers then seized the chance to further denounce the beatings, the wounds and the other cruelties they suffered and the murders of their comrades committed by the planters. Gathered in the Commission Report in 1876, their testimonies played a key role in ending the "coolie" trade to Cuba one year later. ${ }^{39}$

Slave agency similarly stemmed from the complex interaction between punishment administered by the landowners and that enforced by the State, through the mediating role of legal rights. Alejandro de la Fuente has highlighted that the creation of legal rights for the enslaved people of Cuba was based on key principles established already in the medieval Spanish code of the Siete Partidas, which allowed them to address "excessive punishments", "ill treatments" and the failure of masters to provide an appropriate quantity of food. ${ }^{40}$ Repeatedly confirmed from the sixteenth to the eighteenth centuries, those customary rights were not hampered by the transition of Cuba into a plantation and slave society in the late eighteenth and early nineteenth centuries. On the contrary, the "Black Code" (Código Negro) of 1789 and the Reglamento de esclavos of 1842 wrote those customary rights into law and created legal infrastructures to implement them. In the second half of the nineteenth century, while the slave owners' right to punish continued unquestioned until the legal abolition of slavery, new pieces of legislation increasingly imposed legal limitations on their authority. Flogging was outlawed in 1870, the Ley de Patronato of 1880 legislated a scale of offenses for the first time, in 1883 stocks and irons were banished, and in 1890 police surveillance of former patrocinados was lifted. ${ }^{41}$

What might seem a linear development of legal protection can more realistically be described as an expansion of state legislation dealing with the punishment of enslaved workers in the midst of continuous and often successful opposition from slave owners. ${ }^{42}$ In fact, it was the slaves' own action that forced the implementation of some of those rights and the expansion of the boundaries of the legislation itself. This was most probably achieved in a relatively easier way by the enslaved people working in an urban environment, who had better access to the public authorities, and in civil justice matters. However, as Carredano has highlighted in his study on early nineteenth-century Cuba, plantation slaves also actively exposed the abuses of the landowners and the overseers during the trials they were subjected to following murders, in the attempt to be acquitted or to receive lighter punishments. ${ }^{43}$ Moreover, it can be argued, punishment-related slave agency also continued through the phase of criminal enforcement and by means of crime itself, in a way that closely resembled the practices of the Chinese coolies mentioned above. Indeed, the enslaved workers also petitioned to obtain earlier release or have their retención

39 The Cuba Commission Report (1993, esp. p. 66-69).

40 de la Fuente (2007, p. 670). See also the contributions of the same author in: de la Fuente (2004); and Varella, (2011).

41 Midlo Hall (1971, p. 108-109).

42 Three cases of successful masters' opposition are those against the Black Code of 1789, the Reglamento de esclavos of 1842 and the abolition of the use of stocks and chains in 1880. See esp.: Scott (2000, p. 172-181); Tardieu (2003).

43 Amores Carredano, (2009). 
lifted, sometimes foregrounding their contribution as impressed soldiers and forced labourers. Furthermore, the very act of murdering an overseer or the master might be seen not only as a reaction to continuous abuses, but also as a risky strategy to escape the violent world of the plantation as a whole. After all, in arguing that only corporal punishments effectively scared and disciplined the slaves, the members of the Cuban elite insisted that presidio sentences and forced labour "do not intimidate, especially slaves" and that the latter "looked with favour to the condition of presidiario, in order to free themselves from their tasks in their master's house or finca" ${ }^{44}$ One does not have to accept their argument about the "comforts" of State-enforced punishment to acknowledge that, under certain circumstances, imprisonment, transportation and convict labour might be perceived as preferable to life and punishment on the plantation.

\section{EXPLOITING CONVICT LABOURERS}

State-enforced punishment was structurally connected with the advantages of exploiting the convicted workforce. Within the Spanish empire, convict labour was traditionally employed in the building of fortifications and other military infrastructures. From the last two decades of the eighteenth century, it also contributed to non-military public and municipal works, such as those that reshaped the Cuban capital according to the models of Western "modernity", "hygiene" and "progress". 45 In the early 1830s, convicts additionally formed part of the multifaceted workforce that built the first Cuban railways. In 1858, the new Rules for the presidios of the island established a noteworthy administrative separation between military and civil punitive institutions, but continued to foreground the centrality of labour as, and in, punishment. ${ }^{46}$ The military fortifications in La Cabaña and the Morro remained locations of convict labour and those functions of convict labour also expanded to the depositos de cimarrones after their institution in 1796. Captured enslaved and indentured workers held there were systematically used as forced labourers while waiting for their owners and contractors to collect or re-sell them. If that did not happen, they officially passed to State ownership. In both cases, they were employed in a large range of public and private works, including the construction of the Habana-Guïnes railway. ${ }^{47}$ Sources from the 1830 s reveal that those held in the Havana deposito were also illegally coerced into domestic service. ${ }^{48}$

The main advantage of convict labour was its flexibility: it could be employed in different economic sectors, exploited by the State or leased out to privates, and relocated at any time according to need. Prisons, presidios and the depositos de cimarrones were the primary repositories of such flexible forced labour. In December 1871, for example, convicts held in the presidio of Havana were employed in the cigar, shoe and tobacco workshops within the prison, in the construction of streets, the

\footnotetext{
44 Quoted in Escalona Sanchez (2005, p. 309-310).

45 García (2016). On crime and social control in Havana, see: Díaz Martinez (2005, 2011, 2012).

46 Reglamento que establece y manda observar en los presidios, Habana, Imprenta del Gobierno y Capitania General por S.M., 1858.

47 Moreno Fraginals (2001, p. 241-242).

48 AHN, Ultramar, 9, exp. 2.
} 
sewer and the aqueduct in the city, and in the railway between Cardenas and Tucano. They also worked in stone quarries and repaired the building of the Escuelas Pias in Guanabacoa. ${ }^{49}$ The duration of the employment varied and convicts employed in building works, in particular, were frequently moved from one construction site or quarry to the other. The number of the convicted workers on a single site similarly shifted according to the needs of production and in relation to the availability of other types of manpower.

The practice of leasing out convicts to landowners emerged in 1868 and took off around the mid-1870s. As the 1870 s advanced, a clear tendency emerged to shift the convicts from public works to private plantations. ${ }^{50}$ In May 1883, at least nine hundred convicts from the three major penal institutions - Havana, Puerto Principe and Isla de Pinos - worked on private plantations. Within the presidio of Havana, in the first half of the 1880s more penados were employed in that destination than in public works. This noteworthy deviation from the standard approach of the Spanish authorities to convict labour - which, as a rule, was not employed in agriculture - clearly related with the need to provide a complementary workforce for the plantations in the midst of military conflict, after the partial abolition of slavery (1870), the definitive end of the illegal slave trade (1873) and the discontinuation of the coolie trade (1874), and during the years of the patronato. And yet, as Balboa Navarro has observed, in Cuba "convicts were a transitional solution" for a transitional period, rather than a durable alternative for the labour needs of the post-emancipation plantations. ${ }^{51}$ The local and metropolitan decision-makers were fully aware that "by allocating some 350 convicts on average to the agricultural works, the total of such labour cannot provide a considerable advantage but to a few planters" ${ }^{2}$

Rather than part of a grand plan to substitute the enslaved workforce, the employment of convicts in plantations stemmed from the joint interests of a section of the landowners and the State. The former received a useful and cheap complement to their ever insufficient workforce. From the perspective of the public authorities, leasing out convicts to private employers was convenient especially in financial terms, for it allowed the State to save most of the cost of maintenance of the prisoners and additionally brought significant revenues in the Royal Treasury. Out of a standard "wage" (jornal) of twelve pesos oro paid by the landowners, one was deposited in a "saving fund" (fondo de ahorro) that was given to the convict on release, two were aggregated to the "benefit fund" (fondo de utilidad) of the penitentiary institution and nine pesos oro were directly appropriated by the Tesoro. The percentage of revenue was also higher in the case of leasing out convicts to planters than to private companies involved in building works. Further advantages for the State could be obtained by manipulating the jornal itself, for any increase resulted in a growth of the part destined to the Treasury, the funds of the convicts and the prison remaining untouched.

$49 \quad$ AHN, Ultramar, 1833, caja 1.

50 For the Havana presidio: AHN, Ultramar, 1833, caja 1. For the presidio in Puerto Principe: AHN, Ultramar, 1833, caja 1, Liquidación de los ingresos y gastos. For other data in the text: AHN, Ultramar, 1833, caja 2, exp. 451. AHN, Ultramar, 1927, caja 1.

51 Balboa Navarro (2009, p. 268).

52 AHN, Ultramar, 1927, caja 3, Madrid, 6.7.1887. 
However, the public authorities knew that any such modification could only take place "in harmony with the need of the privates and with the remuneration of the totally free labour for rural works" ${ }^{53}$ For this reason, the monthly jornal of the convicts fluctuated considerably in the years 1883-1887, becoming simultaneously a thermometer of the relations between the State and the landowners on the island, an indicator of the wages of the free workers, and a sign of the position of Cuba in the world market. In particular, it indicates the substantial subordination of the State to the interests of the landowners, which in turn made the position of the leasedout convicts especially weak and dangerous. Official documents insisted that "in the works they are employed in, convicts have to be treated as free men", but they were effectively a "doubly coerced workforce", as sentenced individuals and forced labourers. ${ }^{54}$ Notwithstanding the inspections of the authorities on the plantations and the frequent petitions of the penados, the latter suffered not only long (legal) working days, insufficient alimentation and inappropriate accommodations, but also from being forced to work extra-time, on Sundays and beyond the end of the contract, and for the lashes they received even after flogging had been abolished for the enslaved workers.

From 1868 to 1887 , at least 1,732 convicts died, mainly of phthisis and enteritis, their mortality rate standing at $14.89 \%$, or 5.5 times higher than the one experienced by those who remained in the penal institutions or were employed in non-agricultural works. ${ }^{55} \mathrm{~A}$ letter of the Governor general mentioned those figures in June 1887 as one motivation to discontinue old contracts and forbid new. Tellingly, he mentioned two other, less humanitarian reasons for that legislative act, finally passed by a Royal Order of 30 July 1887. On the one hand, the abolition of the convict lease in agriculture was necessary because, in order to avoid mistreatments, convicts escaped "with dishonour of the Authority, as the majority ends up in strengthening the parties of bandits". On the other, the Governor general noted that the "utility for the Treasury is somewhat illusory, for although most of the revenues from convict labour enter there, a considerable part of them has to be invested to hospitalize those who become ill". 56

Convict labour was not just imbricated in the interplays between labour relations in Cuba. Through penal transportation and administrative deportation, convicts expelled from Cuba also became part of the transformation of labour relations in other parts of the empire. For example, some of those expelled in the midst of the Escalera repression ended up as forced labourers in Ceuta, following longestablished patterns of penal transportation in the Spanish empire. In 1896, the ñañigos deported to Fernando Poo were employed in the public works of Santa Isabel, the main urban centre of the West African island. ${ }^{57}$ The Chinese contract workers sentenced for murder of the overseers, drivers and other plantation workers

53 AHN, Ultramar, 1927, caja 3, Havana, 11.11.1882. For the description that follows in the text: AHN, Ultramar, 1927, caja 2. See also, Balboa Navarro (2009, p. 262-276).

54 AHN, Ultramar, 1927, caja 3, Havana 11.11.1882. For "doubly coerced workforce": Balboa Navarro (2009, p. 264).

55 AHN, Ultramar, 1927, caja 3, Havana, 13.6.1887.

56 AHN, Ultramar, 1927, caja 3, Havana, 13.6.1887. In 1888, 202 convicts were still employed in three plantations: Balboa Navarro (2009, p. 278).

57 Aranzadi (2012, p. 43). 
in Cuba also became imbricated in the labour relations in the sites of destination. First deported primarily to Ceuta and Santo Domingo, starting from the early 1860s they were channeled into the public works in Puerto Rico. ${ }^{58}$ In the years between 1857 and 1886, these consisted primarily in the construction of the Carretera central, the $134 \mathrm{~km}-$ long road that connected the capital San Juan with Ponce, and therefore the northern and southern part of the islands, penetrating the Central Cordillera for the first time. ${ }^{59}$ At least from 1874 onwards, convicts provided the entire workforce that built that road, and the same can be said for other roads, bridges, piers and churches that were constructed in the second half of the nineteenth century across the whole Puerto Rico, funded by the government of the island, municipal councils and private capital. ${ }^{60}$ The economic elites of some urban centers along the route of the Carretera Central financed the transportation of 127 convicts from Cuba in the late 1870s and in some cases also profited directly from convicts by hiring them from the State as workforce for their own building companies. ${ }^{61}$

\section{ANTI-VAGRANCY POLICY BETWEEN EXPULSION AND WORK DISCIPLINE}

The repression of vagrancy in nineteenth-century Cuba is a clear example of the adaptability of punishment to shifting social and labour relations and to different spatial contexts. Not only did policies change, but the very conceptualisation of vagrancy (vagancia) evolved in order to target different groups and reach distinct goals. As Díaz Martínez has observed, the very "ambiguity" of the term allowed "addressing any problem or circumstance that might contribute to threaten the stability of the colony, independently from its origin and consequences". ${ }^{62}$ Accordingly, the fight against vagrancy legitimised the persecution of the libres de color in the 1860s and the ñañigos in 1877, and more consistently targeted the marginal population of Havana, the patrocinados of the western plantations and the rural population of Central-Eastern Cuba.

As the network of control set up in Havana during the 1820s expanded in the following decades, the definition of vago broadened up too: from establishing a specific connection with the lack of fixed residence, it came to include playing forbidden games, committing petty crimes, being a foreigner and engaging in extramarital relationships. Besides the Royal prison of Havana, opened in 1836, the Isle of Pines emerged as the most important site of punishment for the urban "vagrants" following the foundation of the administrative centre, Nueva Gerona, at the end of 1830. The function of punishment on that "island of the deportees", as it became known, also changed in time, especially in the period around the abolition of slavery. Up to the early 1870 s, expulsion was its key feature and in

58 The tendency to deport the Chinese coolies to Puerto Rico was later strengthened by Royal Order 27 August 1880: AHN, Ultramar, 5114, Exp. 19. On the Chinese presidiarios in Puerto Rico: Picó (1994, p. 41-42).

59 AHN, Ultramar: 2078, Exp. 2; 2078, Exp. 3; 2080, Exp. 3, 4, 13, 14, 21, 23, 24; 2081, Exp. 4.

60 AHN, Ultramar, 370, Exp. 15, 16, 17. See also Picó (1994, p. 109).

${ }_{61}$ AHN, Ultramar, 370, Exp. 15, Donnet, Madrid 21.9.1880. For some examples of convicts leased to private employers: AHN, Ultramar, 5104, Exp. 7, Puerto Rico, 19.6.1873.

62 Díaz Martínez (2011, p. 70). 
the profiles of those deported, vagrancy was closely associated with crime. ${ }^{63}$ The goal of the authorities was to remove from the capital city those who were deemed as "incorrigibles" (incorregibles), that is, repeated offenders sentenced to corporal punishment or presidio by ordinary courts. ${ }^{64}$ In the mid-1870s, however, the situation changed. The difficulties of simply "depositing" the incorrigibles on the Isle of Pines, the problems that administrative deportations created in the destinations across the empire and the approaching of the abolition of slavery triggered a shift in confinement in the Isle of Pines: from mere expulsion to relocation accompanied by preventive and rehabilitative goals.

Labour held a two-fold centrality in this endeavour. On the one hand, the repression of vagrancy was now linked with the need to "create in them [the vagrants] a habit of industriousness"; on the other hand, deportation was connected with the "development of agriculture and industry" on the Isle of Pines itself. 65 The profile of the "vagrants" who were deported changed accordingly. In the second half of the 1870s and the early 1880s, the expedientes de vagancia (vagrancy files) were clearly separated from the criminal cases. The focus now lay on the continuity of employment, "bad conduct" was associated with "working neither in his craft nor for others with regularity", and those suspected of vagrancy had to "substantiate their industriousness" and show that they "dedicated themselves with more perseverance to work" ${ }^{66}$ In other words, "vagrancy" in this context became a synonym of individual workers being held responsible for their unemployment and underemployment. The institutional landscape of the Isle of Pines was modified too. A Protectorado del trabajo (Labour Protectorate) was created to organise the employment of the vagrants and other convicts on the island. Between the end of 1874 and the beginning of 1875 , the convicts were forced to build a Correccional de Vagos (correctional institution for vagrants) with a capacity of 800-1,000, including both intramural workshops and buildings for vagrants employed outside the institution, especially in the quarries, the cutting of wood and in some small plantations. ${ }^{67}$

In the 1880 s the picture changed again, in connection with the end of the patronato and the landowners' and policy-makers' preoccupations that former slaves would leave agriculture en masse, thus creating the collapse of the plantation economy of the western part of the island. An extensive debate on vagrancy took place between 1881 and 1889, which was about designing legal measures that would allow immobilising on the plantation the previously enslaved workforce: these ranged from cautious decriminalisation to the establishment of houses of corrections and compulsory impressment in the army of all blacks between eighteen and twenty-eight years of age. ${ }^{68}$ In the end, the Protectorado and the Correccional were abolished and the governor of the Havana prison rejected new propositions to turn the isle of Pines into a penitentiary colony ${ }^{69}$ However, as the feared outflow of

63 AHN, Ultramar, 4709, caja 1; AHN, Ultramar, 4718, exp. 5.

${ }^{64}$ AHN, Ultramar, 4718, exp. 5, Havana, 15.8.1866, n. 270 and 28.2.1864, n. 79.

65 AHN, Ultramar, 4718, Havana, 28.3.1866.

66 A large collection of expedientes de vagancia are held in AHN, Ultramar, 3859, cajas 1-3.

${ }_{67}$ AHN, Ultramar, 1833, exp. 464, Havana, 28.4.1875.

68 The debate is synthetized in Scott (2000, p. 219-221).

69 AHN, Ultramar, 1833, exp. 464, Havana, 17.1.1885 and 28.2.1885; Madrid, 12.3.1885; AHN, Ultramar 1927, caja 3, 11.7.1887. 
plantation workers did not take place in Cuba in the years immediately following October 1886, the envisaged large-scale criminalisation of the plantation workers' "vagrancy" proved unnecessary, none of the options proposed by the Cuban elites was implemented, and anti-vagrancy policy continued to target primarily selected groups of urban poor in order to "help discipline the rest". 70

Besides the Cuba of the urban centres and the western sugar plantations, a third Cuba existed in the central-eastern part of the island, and from the late 1870s onwards anti-vagrancy came to play an important role there, as a means to discipline the rural population. ${ }^{71}$ This was a region where the impact of slavery and sugar had always been less significant, with wage labourers and independent peasants prevailing within an economy primarily based on cattle farming and the cultivation of multiple types of crops. At the same time, central and eastern Cuba was the cradle of the Cuban insurrection, whose main strategic limitation during the Ten Years War and the Guerra Chiquita had laid precisely in the impossibility to expand to the western part of the island. Those military conflicts led to extensive destruction of the agricultural production and the subsequent reconstruction made the centraleastern part of Cuba an especially dynamic part of the economy in the years around the abolition of slavery. As such, it became the ground for multiple experiments in labour, colonization and migration policies. ${ }^{72}$ The repression of vagrancy intervened in those transformations and, in the process, the concept of rural "vagrancy" became associated with that of bandolerismo, or rural banditry, and with anti-insurgency.

In October 1879, the extension to Cuba of the anti-banditry and anti-vagrancy law of the peninsula was designed to "smash any independentist effort and any other act of rural protest" and associate insurgency to non-political criminality. ${ }^{73}$ Moreover, those repressive measures gave the authorities powerful new instruments to control the rural workers at large in those years of major social and economic transformations. This broader repressive action took two, partially intertwined, forms. On the one hand, hundreds of men and women were targeted for deportation to the Isle of Pines under the suspect of being "accomplices" or "accessories" of the bandits. ${ }^{74}$ This repressive practice reached a remarkable level of efficiency between August 1890 and June 1892, when Governor general Polavieja created a special antibanditry institution - the Gabinete Particular -, and continued through the years of the War of Independence (1895-1898) ${ }^{75}$ On the other hand, between 1878 and 1898 , military strategies, colonization and the widespread mistrust in the political loyalty of the central-eastern rural population converged to determine the mass relocation of tens of thousands of civilians (pacificos). The tragic culmination of such policy was reached with the process of reconcentración (re-concentration) implemented by Captain general Valeriano Weyler between February 1896 and November 1897. In that period around three hundred thousand of men, women and children were

$70 \quad$ Scott (2000, p. 224); Balboa Navarro (2011, p. 100-103).

71 On the importance of regional differentiations in the Cuban society and economy: Venegas Delgado (2005).

72 Balboa Navarro (2000).

73 Balboa Navarro (2003, p. 94-95). On the connection between banditry, insurrection and peasant protest: Pérez Jr. (1989); Schwartz (1989).

74 AGI, Diversos, 19.

75 In 1896-1897, 298 men and 21 women were confined in the Isle of Pines: AHN, Ultramar, L. 666. 
forced to move to urban centres fortified and defended by the Spanish troops, where "cultivation zones" were set up but proved largely insufficient to feed them: between 155,000 and 170,000 persons died of starvation and epidemics. ${ }^{76}$ As Lawrence Tone has made clear, war-time reconcentración, was primarily "designed to deny the insurgents access to civilians and their resources by controlling or eliminating them" ${ }^{77}$ However, it also originated from smaller-scale and less deadly experiences of counter-insurgency, forced migration and colonization that dated back at least from the first months of the Ten Years War and continued in the period of reconstruction in the central-eastern part of the island. ${ }^{78}$

\section{PUNITIVE PLURALISM AND MULTIPLE LABOUR RELATIONS}

This article has looked simultaneously at multiple punitive regimes and multiple labour relations in Cuba in the decades between the abolition of the slave trade and the abolition of the patronato. Four main functions of punishment can be foregrounded in connection with labour relations and their shifts. First, preventive and repressive measures were instrumental in preserving the political, social and racial order and avoiding regime changes that might impact on social and labour relations. In particular, the construction of a cordon sanitaire against potential subversive elements from abroad and the expulsion of "internal enemies" served this goal. Second, punishment allowed for a direct intervention against specific groups of the population in order to modify the composition of the workforce in certain economic sectors, as in the case of the repression of the libres de color, and regulate the relationship between workers and unemployed/underemployed, especially through the anti-vagrancy laws.

Third, through the production of convict labour, punishment enhanced the fluidity of labour relations, by turning enslaved people, indentured workers, wage labourers and other groups of free and coerced workers into convicted labourers. On that basis, it intervened in the labour market through the creation of a highly flexible and mobile coerced workforce that might complement or substitute other labour relations in a broad range of economic contexts: from military infrastructures to urban works and railways and from the plantations to the households. Fourth, while punishment directly targeted relatively small groups, it played an explicit disciplining function vis-à-vis the (especially subaltern) population as a whole: thus, enslaved people were sentenced to death or hit with the lash in front of their fellow workers; individual "vagrants" were persecuted to "moralise the working classes of Cuba"; ${ }^{79}$ and some hundreds of libres de color were expelled in order to de-structure the whole free black community of the island.

These four functions co-existed, and the plurality and flexibility of punishment allowed for its adaptation to, and intervention in, shifting combinations of labour relations across different spaces and times. In other words, because various types of punishments existed simultaneously, they were able to cope with slaves, coolies

\footnotetext{
76 Tone (2006, p. 223 and detailed table on p. 212).

77 Tone (2006, p. 206).

78 Tone (2006, p. 195-196); Polavieja (1880, p. 91).

79 AHN, Ultramar, 1833, exp. 464, Havana, 10.9.1874.
} 
and wage labourers and control urban abakuas, rural bandoleros and foreigners. Moreover, they intervened in the distinct combinations of labour relations that existed in the main urban centres, the western plantations and the eastern regions in decades of momentous change that repeatedly reshaped those very combinations. The four functions also entangled in specific punitive institutions and sites by targeting different groups. Prisons temporarily hosted foreign abolitionists, insurgents and enslaved workers due to be returned to their masters; at the same time, they were repositories of convict labour employed across the island. Similarly, the Isle of Pines was envisaged as an exile for incorregibles and laborantes, a site of incarceration for common criminals and a penitentiary colony for vagrants, and often performed those functions simultaneously. Dynamics of control on certain groups of workers also expanded to others, notwithstanding legal differentiations. Most strikingly, in the western plantations, the punitive patterns of the Chinese contract workers overlapped with those of the enslaved people of African descent, even though the former were officially conceptualised as "whites" and "free". Finally, the flexibility and expansiveness of punishment also stemmed from the fluidity of the categories that legitimised repression. "Vagrancy" is a case in point, covering the large grey zone between crime and urban labour discipline, being central in anti-bandit and anti-insurgency policies, and allowing for the criminalization of the rural civil population at large.

Spatial mobilization and immobilization were the two key mechanisms by which punishment intervened in social and labour transformations. Expulsion kept external and internal enemies at bay, disarticulated social and labour relations and produced both exemplary terror and a sense of community in those who remained. Immobilization, by attaching an individual to one specific place or working site, served the goals of surveillance as well as enhancing colonization and labour extraction. The two mechanisms were not mutually exclusive. Within Cuba, imprisonment went together with mobilization of convict labour in public works and private plantations, and the expulsion of a "vagrant" might imply his/her relocation to the Isle of Pine or another site of convict labour. Moreover, through convict transportation, the relocation of a convict from Cuba often connected with the extraction of his (and more rarely her) labour power in another location across the Spanish empire.

These empirical findings allow for broader reflections on methodology and theory. By studying simultaneously (some of) the labour relations existing in Cuba during the nineteenth century, this article has highlighted that they combined differently in multiple contexts, and that the abolition of slavery did not entail a linear transition to "free" wage labour, but rather a more complex shift to various combinations of wage labour, convict labour, indenture and subsistence labour. At the same time, the concept of "punitive pluralism" has drawn attention not only to the multiple types of punishment that were used, but also to their various sources (both within and beyond state law), and to their flexible applications to diverse groups of populations in spatially highly differentiated environments. Clearly, punishment played an important role in the creation, control and management of a multifaceted and rapidly changing workforce. It was able to play that role precisely because of its own plurality and flexibility, that is, because it did not converge towards one single punitive regime. Therefore, the simultaneous pluralization of labour and punishment is strategic to grasp the complexity of their relationship, whereas the exclusive focus on one labour relation and one type of punishment, which has hitherto been the standard in the scholarship, misses the essence of this process. 
Thus, the approach proposed in this article draws attention to multiple combinations of punitive forms and labour regimes, and to contextual and temporal discontinuities, and avoids the over-simplification and distortion attached to predefined models of linear evolution of labour and punishment. It reveals how workers imbricated in a single labour relation were targeted by multiple types of punishments; it shows how one kind of punitive institution, like transportation or imprisonment, served several labour-related goals; and it highlights how multiple punitive and labour regimes were applied in one single region or site.

It is argued that the conceptualization proposed in this article can be employed in the analysis of the connections between punishment and labour relations in other spatial and chronological contexts. This does not mean that the functions and mechanisms highlighted for nineteenth-century Cuba are all necessarily and simultaneously relevant across other chronological and geographical contexts. Rather, they might serve as references for studies on other contexts to address aspects that have hitherto been overlooked, as much as they can be enriched, and questioned, by new empirical research.

Arguably, the frame proposed in this article is sufficiently flexible to accommodate many different combinations of punitive and labour regimes while at the same time retaining its heuristic value. In particular, some key questions raised here are likely to be applicable across the field. These include asking: why and how various forms of punishment have enhanced the fluidity of labour relations in a given context and in the lives of individual workers; the logic by which they have been selectively applied to specific groups of workers across time and space; why and how they have supported shifts in combinations of labour relations; what has been the contribution of punishment to the mobilization and immobilization of the workforce; and finally, under which circumstances the existence and interaction between labour regimes have shaped specific forms of punishment.

While offering a broad epistemological frame for the study of the entanglements of punishment and labour in a long-term perspective, the conceptualization proposed in this essay also enables comparative research on more specific aspects. The Cuban case discussed here highlights this potential. The systematic recourse to the expulsion of the libres de color in Cuba, for example, resonates with the uncertainty of the legal and social status of the free black population that has been observed in other slave societies across the Atlantic world ${ }^{80}$ Furthermore, the multiple functions of incarceration vis-à-vis distinct groups of workers in Cuba echo those which have been foregrounded for colonial incarceration at large.$^{81}$ Moreover, the dialectics of domestic and state-administered punishment described in this article for the plantations of western Cuba strongly resonates with the findings of the literature on the punishment of enslaved workers in the eighteenth- and nineteenth-century US South, Jamaica, Brazil and other Latin American settings. ${ }^{82}$ At the same time, scholars of other contexts may want to engage with the contention made here regarding the substantial overlapping of the punishment for slaves and other (allegedly "free") plantation workers, especially when indenture was concerned. The focus of this

$80 \quad$ Chalhoub (2012); Morelli and Thibaud (2015); Mamigonian (2017).

81 Bernault (1999, esp. chapters 5-9); Dikötter and Brown (2007); Anderson, (2008).

82 Schwartz (1988); Hunold Lara (1988); Morris (1996); Paton (2004); McNair (2009); Scott (2011); Machado (2014); Harris (2017). 
article on punishment, rather than criminal and civil justice, might also provide a substantial expansion for the excellent contributions that especially Latin American historians have made in the study of slaves' use of the law..$^{83}$

On other issues, the Cuban case indicates significant divergences vis-à-vis the patterns that have been observed in other contexts. The role of convict labour around the abolition of slavery is a case in point. Scholars of post-emancipation US South have clearly identified the tendency for convict labour to be instrumental in immobilizing the ex-slaves in the plantations and in the "modernization" of that part of the country. ${ }^{84}$ Conversely, convict labour in Cuba after 1886 was temporarily used in the plantation during the years around the abolition of slavery and the patronato as a complement to other labour relations. Was that difference - one may ask - the result of the different timing of abolition in the US South and Cuba, the former being the sudden product of the Civil War and the second following decades of discussions, gradual abolition and social engineering? Indeed, the expected flows of the ex-slaves from the western plantation did not take place in Cuba and the anti-vagrancy policies designed to prevent it were re-oriented against other sectors of the island's population, namely the urban poor and the Eastern peasantry. At the same time, just as in Cuba, the penal system in Puerto Rico was to local free peasants a part of a circuit of control and compulsion aimed to transform them into (waged) agricultural labourers. ${ }^{85}$ This function of anti-vagrancy policies as a tool to transform large sectors of the subaltern population into commodified labour has a long-term and almost universal history, and deserves further examination. ${ }^{86}$ Also in this perspective, the Cuban case stands out as a key reference in the global and comparative history of punishment and labour, and the analytical frame proposed here will, it is hoped, facilitate future explorations.

Christian De Vito

Bonn Centre for Dependency and Slavery Studies

University of Bonn christian.devito@gmail.com

\section{BIBLIOGRAPHY}

Álvarez Cuartero, I., De Tihosuco a La Habana. La venta de indios yucatecos a Cuba durante la guerra de castas, Studia histórica. Historia antigua, 2007, 25, p. 559-576.

Amores Carredano, J.B., Justicia y esclavitud: Cuba, 1800-1820, Anuario de Estudios Americanos, 2009, 66, 1, p. 79-101.

Anderson, C., The politics of punishment in colonial Mauritius, 1766-1887, Cultural and Social History, 2008, 5, 4, p. 411-422

Anderson, C. (Ed.), A Global History of Convicts and Penal Colonies, London, Bloomsbury, 2018.

\footnotetext{
83 Chalhoub (2001); Azevedo (2010); McKinley (2016).

84 Lichtenstein (1996).

85 Santiago-Valles (1996, p. 128).

86 For example: Lovejoy and Rogers (1994, p. 71-150).
} 
Azevedo, E., O direito dos escravos. Lutas jurídicas e abolicionismo na província de São Paulo, Campinas, Editora Unicamp, 2010.

Balboa Navarro, I., Los brazos necesarios. Inmigración, colonización y trabajo libre en Cuba, 1878-1898, Valencia, Fundación Instituto de Historia Social, 2000.

Balboa Navarro, I., La protesta rural en Cuba. Resistencia cotidiana, bandolerismo y revolución (1878-1902), Madrid, CSIC, 2003.

Balboa Navarro, I., Presidiarios por esclavos. Mano de obra cautiva en la transición al trabajo libre, in Piqueras, J.A. (Ed.), Trabajo libre y coactivo en sociedades de plantación, Madrid, Siglo XXI de España, 2009, p. 253-279.

Balboa Navarro, I., Libertos, vagos y bandoleros. La reglamentación del trabajo tras la abolición de la esclavitud (Cuba, 1886-1895), Relaciones, 2011, 127, 32, p. 87-116.

Barcia, M., Seeds of Insurrection. Domination and Resistance on Western Cuban Plantations, 1808-1848, Baton Rouge, Louisiana State University Press, 2008.

Barrio Gonzalo, M., Esclavos y cautivos. Conflicto entre la cristiandad y el islam en el siglo XVIII, Valladolid, Junta de Castilla y León, 2006.

Benton L. Ross, R.J. (Eds.), Legal Pluralism and Empires, 1500-1850, New York, New York University Press, 2013.

Bernault, F. (Ed.), Enfermement, prison et châtiments en Afrique du $19^{e}$ siècle á nos jours, Paris, Karthala, 1999.

Brass, T. van der Linden. M. (Eds.), Free and Unfree Labour: The Debate Continues, Leiden and Boston, Brill, 1997.

Chalhoub, S., Visões da liberdade. Uma história das últimas décadas da escravidão na Corte, São Paulo, Schwarcz, 2001.

Chalhoub, S., A força da escravidão: Ilegalidade e costume no Brasil oitocentista, São Paulo, Companhia das Letras, 2012.

Claustre, J., Dans les geôles du roi. L'emprisonnement pour dette à Paris à la fin du Moyen Âge, Paris, Publications de la Sorbonne, 2007.

de Aranzadi, I., El legado cubano en África. Ñañigos deportados a Fernando Poo. Memoria viva y archivo escrito, Afro-Hispanic Review, 2012, 31, 1, p. 31-62.

de la Fuente, A. (Ed.), Los esclavos y la ley, Debate y perspectivas, special issue, 2004, 4.

de la Fuente, A., Slaves and the Creation of Legal Rights in Cuba: Coartación and Papel, Hispanic American Historical Review, 2007, 87, 4, p. 659-692.

De Vito, C.G., Connected Singularities. Convict Labour in Late Colonial Spanish America (1760s-1800), in De Vito C.G. Gerritsen, A. (Eds.), Micro-Spatial Histories of Global Labour, London, Palgrave, 2018a, p. 171-202.

De Vito, C.G., The Spanish Empire, 1500-1898, in Anderson, C. (Ed.), A Global History of Convicts and Penal Colonies, London, Bloomsbury, 2018b, p. 65-96.

De Vito, C.G., Punitive Entanglements: Connected Histories of Penal Transportation, Deportation, and Incarceration in the Spanish Empire (1830s-1898), International Review of Social History, Special Issue 2018c, p. 1-21.

De Vito, C.G. Futselaar, R., Grevers, H. (Eds.), Incarceration and Regime Change. European Prisons during and after the Second World War, Ney York, Berghahn, 2017.

De Vito, C.G., Anderson, C., Bosma, U., Transportation, Deportation and Exile: Perspectives from the Colonies in the Nineteenth and Twentieth Centuries, International Review of Social History, Special Issue 2018, p. 1-24.

De Vito, C.G., Schiel, J., van Rossum, M., From Bondage to Precariousness? New Perspectives on Labor and Social History, forthcoming.

Díaz Martinez, Y., La peligrosa Habana. Violencia y criminalidad a finales del siglo XIX, Havana, Editorial de Ciencias Sociales, 2005. 
Díaz Martinez, Y., Visión de la otra Habana: Vigilancia, delito y control social en los inicios del siglo XIX, Santiago de Cuba, Editorial Oriente, 2011.

Díaz Martinez, Y., De marginados a trabajadores. Usos y destinos de la población penal en La Habana, Millars, 2012, 35, p. 129-149.

Dikötter, F. Brown, I. (Eds.), Cultures of Confinement. A History of the Prison in Africa, Asia and Latin America, London, Hurst \& Company, 2007.

Dorsey, J.C., Identity, Rebellion, and Social Justice Among Chinese Contract Workers in Nineteenth-Century Cuba, Latin American Perspectives, 2004, 136, 31, 3, p. 18-47.

Duve, T. (Ed.), Entanglements in Legal History: Conceptual Approaches, Berlin, Max Planck Institute for European Legal History, 2014.

Duve, T. (Ed.), Global Legal History - A Methodological Approach, Max Planck Institute for European Legal History, research paper series, 2016, 4, p. 1-22.

Escalona Sanchez, M.S., Los momentos que preceden a la "Conspiracion de la Escalera" en la jurisdiccion de Matanzas, Annales del Museo de America, 2005, 13, p. 301-316.

Ferrer, A., Insurgent Cuba. Race, Nation, and Revolution, 1868-1898, Chapel Hill and London, The University of North Carolina Press, 1999.

Ferrer, A., Freedom's Mirror. Cuba and Haiti in the Age of Revolution, Cambridge, Cambridge University Press, 2014.

Finch, A.K., Rethinking Slave Rebellion in Cuba. La Escalera and the Insurgencies of 1841 1844, Chapel Hill, The University of North Carolina Press, 2015.

Foner, P.S., A History of Cuba, New York, International Publishers, 1962.

Foucault, M., Surveiller et punir. Naissance de la prison, Paris, Gallimard, 1975.

García, G., Beyond the Walled City. Colonial Exclusion in Havana, Oakland, University of California Press, 2016.

Geltner, G., The Medieval Prison. A Social History, Princeton, Princeton University Press, 2007.

Ghobrial, K., Réformisme et esclavage á Cuba (1835-1845), Paris, Publibook, 2009.

Gibson, M., Global Perspectives on the Birth of the Prison, The American Historical Review, $2011,116,4,1$.

González-Ripoll M.D. et al., El rumor de Haití en Cuba: Temor, Raza y Rebeldía, 1789-1844, Madrid, CSIC, 2004.

Groen-Vallinga, M.J., Tacoma, L.E., Contextualising Condemnation to Hard Labour in the Roman Empire, in De Vito, C.G., Lichtenstein, A. (Eds.), Global Convict Labour, Leiden, Brill, 2015, p. 49-78.

Harris, D.P., Punishing the Black Body. Marking Social and Racial Structures in Barbados and Jamaica, Athens, The University of Georgia Press, 2017.

Helg, A., Our Rightful Share. The Afro-Cuban Struggle for Equality, 1886-1912, Chapel Hill and London, The University of North Carolina Press, 1995.

Helly, D., Idéologie et ethnicité. Les Chinois Macao à Cuba: 1847-1886, Montreal, Les Presses de l'Université de Montréal, 1979.

Hu-DeHart, E., Chinese Coolie Labor in Cuba in the Nineteenth Century: Free Labor or Neoslavery?, Contributions in Black Studies, 1994, 12, p. 38-54.

Hunold Lara, S., Campos da violência. Escravos e Senhores na Capitania do Rio de Janeiro 1750-1808, Rio de Janeiro, Paz e Terra, 1988.

Jennings, E.P., The Sinews of Spain's American Empire: Forced Labor in Cuba from the Sixteenth to the Nineteenth Centuries, in Donoghue, J. Jennings, E.P. (Eds.), Building the Atlantic Empires. Unfree Labor and Imperial States in the Political Economy of Capitalism, ca. 1500-1914, Leiden and Boston, Brill, 2016, p. 25-53. 
Knight, F.W., Slave Society in Cuba during the nineteenth century, Madison, The University of Wisconsin Press, 1970.

La Rosa Corzo, G., Runaway Slave Settlements in Cuba. Resistance and Repression, Chapel Hill and London, The University of North Carolina Press, 2003.

Lichtenstein, A., "Twice the Work of Free Labor": The Political Economy of Convict Labor in the New South, London, Haymarket, 1996.

Linden, van der, M., Workers of the World. Essays Toward a Global Labor History, Leiden and Boston, Brill, 2008.

Llaverías, J., La Comision Militar ejecutiva y pemanente de la isla de Cuba, La Habana, Imprenta "El siglo XX", 1929.

Lo Basso, L., Uomini da remo. Galee e galeotti nel Mediterraneo in età moderna, Milano, Selene, 2004.

Lovejoy, P.E. Rogers, N. (Eds.), Unfree Labour in the Development of the Atlantic World, Ilford, Frank Cass, 1994.

Lucassen, J., Global Labor History. A State of the Art, Bern, Peter Lang, 2006.

Machado, M.H.P.T., Crime e escravidão. Trabalho, Luta e Resistência nas Lavouras Paulistas (1830-1888), São Paulo, Edusp, 2014 (first edition 1987).

Maia Mata, I., Conspirações da raça de cor. Escravidão, liberdade e tensões raciais em Santiago de Cuba (1864-1881),Campinas, Unicamp, 2016.

Mamigonian, B.G., Africanos livres. A abolição do tráfico de escravos no Brasil, São Paulo, Companhia das Letras, 2017.

Martínez Martínez, M., Los forzados de marina en la España del siglo XVIII (1700-1775), Almería, Universidad de Almería, 2011.

McKinley, M.A., Fractional Freedoms: Slavery, Intimacy, and Legal Mobilization in Colonial Lima, 1600-1700, Cambridge, Cambridge University Press, 2016.

McNair, G., Criminal Injustice. Slaves and Free Blacks in Georgia's Criminal Justice System, Charlottesville and London, University of Virginia Press, 2009.

Melossi, D. Pavarini, M., The Prison and the Factory: Origins of the Penitentiary System, London, The MacMillan Press Ltd., 1981.

Midlo Hall, G., Social Control in Slave Plantation Societies. A Comparison of St. Domingue and Cuba, Baton Rouge and London, Louisiana State University Press, 1971.

Miller, I.L., Voice of the Leopard. African Secret Societies and Cuba, Jackson, University Press of Mississippi, 2009.

Moran, D. Gill, N. Conlon, D. (Eds.), Carceral Spaces: Mobility and Agency in Imprisonment and Migrant Detention, Burlington, Ashgate, 2013.

Morelli, F. Thibaud. C. (Eds.), I liberi di colore nello spazio atlantico, Quaderni Storici, special issue, 1 (2015).

Moreno Fraginals, M., El ingenio. Complejo económico social cubano del azúcar, Barcelona, Crítica, 2001 (first edition 1964).

Morris, T.D., Southern Slavery and the Law 1619-1860, Chapel Hill and London, The University of North Carolina Press, 1996.

Naranjo Orovio, C. García González, A., Racismo e Inmigración en Cuba en el siglo XIX, Madrid, Doce Calles, 1996.

Ortiz, F., La “tragedia” de los ñáñigos, Havana, Editorial de ciencias sociales, 1950.

Ortiz-Minaya, R., From Plantation to Prison: Visual Economies of Slaves Resistance, Criminal Justice, and Penal Exile in the Spanish Caribbean 1820-1886, PhD dissertation, State University of New York at Binghampton, 2014.

Paquette, R.L., Sugar is Made with Blood. The Conspiracy of La Escalera and the Conflict between Empires over Slavery in Cuba, Middletown, Wesleyan University Press, 1988. 
Paton, D., No Bond but the Law: Punishment, Race, and Gender in Jamaican State Formation, 1780-1870, Durham and London, Duke University Press, 2004.

Pérez Jr., L.A., Lords of the Mountains. Social Banditry and Peasant Protest in Cuba, 18781918, Pittsburgh, University of Pittsburgh Press, 1989.

Picó, F., El día menos pensado. Historia de los presidiarios en Puerto Rico (1793-1993), Río Piedras, Ediciones Huracán, 1994.

Polavieja, C., Conspiración de la raza de color descubierta en Santiago de Cuba el 10 de Diciembre de 1880, Santiago de Cuba, Sección Tipográfica del Estado Mayor, 1880.

Reid-Vazquez, M., The Year of the Lash. Free People of Color in Cuba and the NineteenthCentury Atlantic World, Athens and London, The University of Georgia Press, 2011.

Rio, A., Penal Enslavement in the Early Middle Ages, in De Vito, C.G., Lichtenstein, A. (Eds.), Global Convict Labour, Leiden, Brill, 2015, p. 79-107.

Roche y Monteagudo, R., La Policia y sus misterios en Cuba, Habana, Imprenta "La Prueba", 1908.

Roldán de Montaud, I., Origen, evolución y supresión del grupo de negros “emancipados” en Cuba (1817-1870), Revista de Indias, 1982, 42, 169-170, p. 559-641.

Salmorál, M.L., Regulación de la esclavitud negra en las colonias de America Espanola (1503-1886): Documentos para su estudio, Alcala and Murcia, Nuevo Siglo, 2005.

Sánchez-Arcilla Bernal, J. (Ed.), El Arbitrio Judicial en el Antiguo Régimen (España e Indias, siglos XVI-XVIII), Madrid, Editorial Dykinson, 2012.

Santiago-Valles, K.A., "Forcing Them to Work and Punishing Whoever Resisted": Servile Labor and Penal Servitude under Colonialism in Nineteenth-Century Puerto Rico, in Salvatore and Aguirre, The Birth of the Penitentiary in Latin America, p. 122-159.

Schwartz, P.J., Twice Condemned. Slaves and the Criminal Laws of Virginia, 1705-1865, Baton Rouge, Louisiana State University Press, 1988.

Schwartz, R., Lawless Liberators. Political Banditry and Cuban Independence, Durham and London, Duke University Press, 1989.

Scott, R.J., Slave Emancipation in Cuba. The Transition to Free Labor, 1860-1899, Pittsburgh, University of Pittsburgh Press, 2000.

Scott, R.J. (Ed.), Law, Slavery and Justice, Law and History Review, special issue, 2011, 29, 4.

Sellin, J.Th., Slavery and the Penal System, New York, Oxford and Amsterdam, Elsevier Scientific Publishing, 1976.

Sherman, T.C., Tensions of colonial punishment: Perspectives on recent developments in the study of coercive networks in Asia, Africa and the Caribbean, History Compass, 7, 3 (1999), p. 659-677.

Sofela, B., Emancipados. Slave Societies in Brazil and Cuba, Trenton and London, Africa World Press, 2011.

Tardieu, J.-P., “Morir o dominar”. En torno al reglamento de esclavos de Cuba (1841-1866), Madrid and Frankfurt am Main, Vervuert and Iberoamericana, 2003.

The Cuba Commission Report. A Hidden History of the Chinese in Cuba, Baltimore and London, The Johns Hopkins University Press, 1993.

Tone, L., War and Genocide in Cuba 1895-1890, Chapel Hill, The University of North Carolina Press, 2006.

Trujillo y Monagas, J., Los criminales de Cuba, Barcelona, Establecimiento tipográfico de Fidel Giró, 1882.

Varella, C., El canal administrativo de los conflictos entre esclavos y amos. Causas de manumisión decididas ante síndicos en Cuba, Revista de Indias, 2011, 71, 251, p. 109136. 
Venegas Delgado, H., Plantación, plantaciones. Cuba en los 1880, C.M.H.L.B. Caravelle, 2005, 85, p. 63-84.

Wachsmann, N., Hitler's Prisons. Legal Terror in Nazi Germany, New Haven and London, Yale University Press, 2015.

Washburn, D.A., Banishment in the Later Roman Empire, 284-476 CE, New York, Routledge, 2013.

Yacou, A., La longue guerre des nègres marrons de Cuba, Paris, Karthala, 2009.

Yun, L., The Coolie Speaks. Chinese Indentured Laborers and African Slaves in Cuba, Philadelphia, Temple University Press, 2008. 